\title{
Mechanical Ventilation \& Ventricular Assist Devices
}

Editors

JOHN J. MARINI

SRINIVAS MURALI

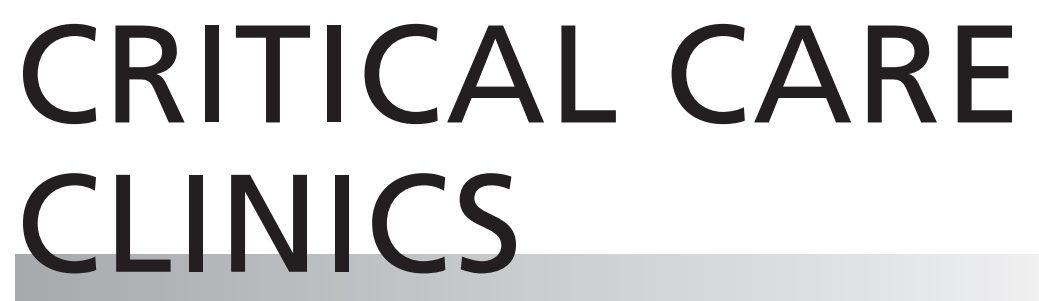

www.criticalcare.theclinics.com

Consulting Editor

JOHN A. KELLUM

July 2018 • Volume 34 - Number 3 